(-) Entomologica Fennica. 14 February 1997

\title{
Some surprising discoveries of Chrysolina relucens (Coleoptera, Chrysomelidae) on the White Sea shore, in Siberia and in the Far East
}

\author{
Andrzej O. Bieńkowski
}

Bieńkowski, A. O. 1997: Some surprising discoveries of Chrysolina relucens (Coleoptera, Chrysomelidae) on the White Sea shore, in Siberia and in the Far East. — Entomol. Fennica 7: 195-199.

Chrysolina relucens (Rosenhauer) is found on the White Sea shore, in Siberia and the Far East. A redescription of the imago and the key to allied species is given. The systematic position, distribution and some biological data are discussed. Chrysolina (Chrysomorpha) relucens is transferred to C. (Anopachys) relucens.

Andrzej O. Bieńkowski, Institute of Animal Evolutionary Morphology and Ecology, Russian Academy of Sciences, Leninsky pr. 33, Moscow, 117071, Russia

Received 22 August 1994, accepted 13 April 1995

\section{Introduction}

Chrysolina relucens (Rosenhauer 1847) was originally described from the environs of Lienz in Tyrol (Austria). It was considered to be an endemic Alpine species (Weise 1916), but later Breit (1920) briefly reported the finding of one female $C$. relucens in Tunkin in the Sajans (Siberia). Bechyné (1952) examined Breit's specimen and suggested that it belongs to some other Chrysolina species from the subgenus Anopachys Motschulsky, 1860, while C. relucens belongs to the subgenus Chrysomorpha Motschulsky, 1860, and is confined to the Alps. It is difficult to ascertain whether Breit's (1920) specimen was $C$. relucens or not, but the available material permits me to assume that his determination was correct.

In 1989 and 1990 I collected 8 specimens (1 male and 7 females) of Chrysolina, that were first identified as C. aurichalcea (Mannerheim, 1825), on the shore of Kandalaksha Bay of the White Sea. However, examination of the male genitalia showed that it was another species altogether, and one which also has several external differences from $C$. aurichalcea. As a result of my examination of the additional material, I found 59 specimens of this unusual species. These specimens were captured in West and East Siberia, the Russian Far East and north-east China and one male in Tyrol! On the one hand, the specimen from Tyrol corresponded with Rosenhauer's description of C. relucens (Rosenhauer 1847), and on the other hand it was identical with the specimens from the White Sea shore, Siberia and the Far East.

C. relucens has still been studied insufficiently in spite of its wide distribution. Modern descriptions are absent, though the male genitalia were recently examined by Warchałowski (1993) and Kippenberg and Döberl (1994). The biology of the species was not investigated. The redescription of the imago and the key to allied species is set out below. The systematic position, distribution and some biological data are discussed. 


\section{Chrysolina relucens (Rosenhauer, 1847) Fig. 1}

Material. 67 specimens (21 males, 46 females): Central Europe: Tyrol, Innsbruck, 1 ex. Northern Europe: Murmansk reg., Kandalaksha Distr., 12 km SE Poyakonda, sea shore, under decaying algae (Fucus) overgrown with Sonchus humilis, 8 ex, 26.VI., 15.VII., 27.VII., 3.VI-3.VIII., 6.VIII., 25.VIII.1989, 18.VI.1990, A. O. Bieńkowski. Western Siberia: Beresow, 1 ex, Bergroth. Eastern Siberia: Yenisei Distr., Rybnoje, 1 ex, 25.IV.-1.V.1899; Yenisei reg., Kansk Distr., Tasejevo, 1 ex, 20.V.1910, Fridolin; Nizh.-Ilimsk, 1 ex, 6.VI.1965, Kreslavskiy; Irkutsk reg., Ilimsk, 1 ex, VI-VII.1902, Ulrikh; Ust-Uda, 1 ex, 17.VI.1849, Yurinski; S. Irkutsk, Upper Kitoi, Angara's tributary, 1 ex, 2.VII.1873, Gartung; S. Irkutsk reg., Tunka, Hal lake, 1 ex, 15.VII.1916, Podgorbunski; Irkutsk envir., Tunka on Irkut, 2 ex, V. Jakovlev; Irkutsk reg., Tunka, 1 ex, 13.VII.1916; Irkutsk reg., Kultuk, 3 ex, 15.VI.1878, Csensopolski; W. Baikal, Listvenichnaja-Goloustnaja, 1 ex, Czekanowski; S. O. Irkutsk, Baikal, Kadilnaja, 1 ex, Czekanowski; Troitskosavsk, riv. Hamneganka and Tsakirka, 1 ex, 7.VI.1902, Mikhno; Irkutsk, 1 ex; riv. Nizh. Tunguska, Kuriy, 1 ex, 27.VI.1873, A. Czekanowski; Buryatia, B. Amalat riv., 1 ex, 6.VII.1968, O. Kabakov; Siberia orient., 1 ex. Russian Far East: Yakutsk reg., Bestiah, 1 ex, 23.V.1912, Naumov; Magadan reg., Gadlja, riv. valley, under stem, 3 ex, 27.VIII.1973, A. Budarin; Okhotsk Sea shore, Arman riv. mouth, 1 ex, 23-24.VIII.1930, Semenov T.-Sh.; Okhotsk Sea shore, Jana riv. mouth, 4 ex, 11.VIII.1930, Semenov T.-Sh.; Okhotsk Sea shore, Jana riv. mouth, 16 km, 2 ex, 16.VIII.1930, Semenov T.-Sh.; Amur reg., Selemdzhinsk, shingle-sand spit, 1 ex, 8.VII.1985, Gubenko; Amur reg., Ekimchan, 2 ex, 2930.VIII.1979, O. Kabakov; Khabarovsk reg, riv. Amgun, Badzhal, 1 ex, 21.V.1980, T. Zhieltikova; between rivers Bureja and Khara, 1 ex; Khabarovsk reg., upper reaches of Urmi riv., 1500 m, 1 ex, 6.VII.1986, S. Kabakov; Khabarovsk Distr., riv. Kur, Garmahta, 1 ex, 15.VIII.1910, Efremov; Khabarovsk Distr., Khekhtsyr, 2 ex, 6.X.1956, O. Kabakov; Khabarovsk Distr., Korfovskij, 2 ex, 1.X.1956, O. Kabakov; N. W. Khabarovsk, Kukan, 1 ex, 7.X.1978, O. Kabakov; Khabarovsk, 1 ex, Speshilova-Petelina; SW Sov. Gavan', riv. Adzhalami, 3 ex, 18.VIII.1965; Chinga Ussuri, 1 ex, VI-VII.1857, Radde; Upper Iodzykhe, 1 ex, 24.VI.1928, Formosov; Primoye, Spasskoe, 1 ex, 3.X.1911, A. Tscherskij; S Ussuri reg., Evsejevka, 1 ex, 8-9.V.1910, N. Shinsarev; Primorye, Kedrovaja Pad', 1 ex, 1.VIII.1968, G. Gornostaev; Amur reg., Pikan, 1 ex, 28.VI.1910, Balts; Yakutsk envir., 1 ex, 28.VIII.1926, Ivanov; Amur, 1 ex, Radde; Dauria, 1 ex, Radde; Amur, 1 ex, Kolbe. N.E. China: Maliy Khingan, 1 ex, 10.IX.1927, Kulmov.

Diagnosis. Specimens of $C$, relucens are recognized by the very shiny, smooth dorsum, black with metallic tinge on head and pronotum, violet colour of elytra (some specimens unicoloured, bronze or blue), convex disc and calli of pronotum, large and deeply punctured lateral impressions of pronotum, and 4 smooth longitudinal bands of elytra; wings developed; aedeagus wide rounded and weakly impressed at apex, without lateral denticles.

Description. Oval (male), or ovate with largest width at distance 1/3 from posterior end (female), equally convex. Above shining, colouration variable: most often bicoloured above: head and pronotum black with strong violet, brass or bronze tinge, elytra violet, violetish black with bronze tinge, or greenish bronze black; some specimens unicoloured above: bronze black, brass black, or blue with weak green and violet tinge (ab. aquilina Bechyné 1948 from the Tyrol); legs and lower surface bluish black, metallic shiny, antennae and palpi brown with bluish black tinge, 1 st and 2 nd antennal joints fulvous below. Head inserted into prothorax up to eyes. Frons and vertex convex, with narrow mid groove, deepening anteriorly, and wide oblique impressions between upper margins of eyes and mid anterior margin of frons, weak shagreened, shining, finely and sparsely punctured, with larger and denser punctures along inner margin of eyes. Clypeus convex, separated from frons with narrow even wide-arched groove, more shagreened, larger and more densely punctured than frons. Labrum convex, anteriorly emarginate, with 2 short setae at each side of depression, 2 long setae on lateral side and row of 1 long and 2 short setae on disc at each side. Antennal insertion slightly closer to clypeus than to eye. Antenna short, slight turn of humeral callus, 2nd-11th joints gradually widened, 2nd and 4th of equal length, $2 / 3$ as long as $3 \mathrm{rd}, 1$ st-6th shining, sparse pubescent, 7 th-11th almost dull, dense fulvous pubescent. Maxillar palp joints 2 nd and 3 rd of equal length and width, latter very slightly widened toward apex, or with parallel sides. Pronotum (Fig. 1e) with very thin edging at all sides, 1.9 as broad as long, deeply emarginate anteriorly, widest basally, almost straight in basal half and roundly narrowed in apical one laterally, or widest medially and rounded on sides, or widest before middle, roundly narrowed anteriorly and weak rectilinear narrowed posteriorly. Anterior angles strongly produced, almost right, widely rounded, posterior ones right, sharp. Disc convex, slightly sha- 

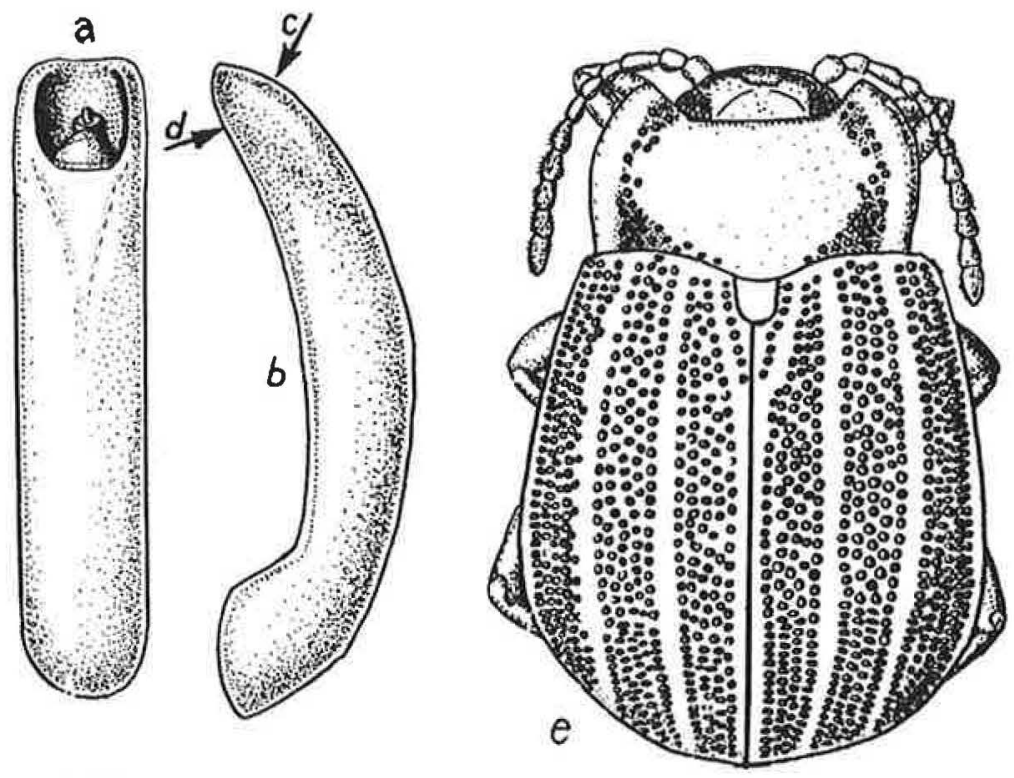

Fig. 1. Chrysolina relucens (Rosenhauer). a-d: aedeagus (male from Murmansk reg.) in dorsal and lateral view, apex in dorsal and ventral view; e: dorsal view (female from Murmansk reg.); $\mathrm{f}-\mathrm{g}$ : apex of aedeagus (male from Tyrol) in dorsal and ventral view; $\mathrm{h}-\mathrm{j}$ : aedeagus in lateral view (males from: Tyrol (h), Beresow (i) and Irkutsk reg. (j)). Scale
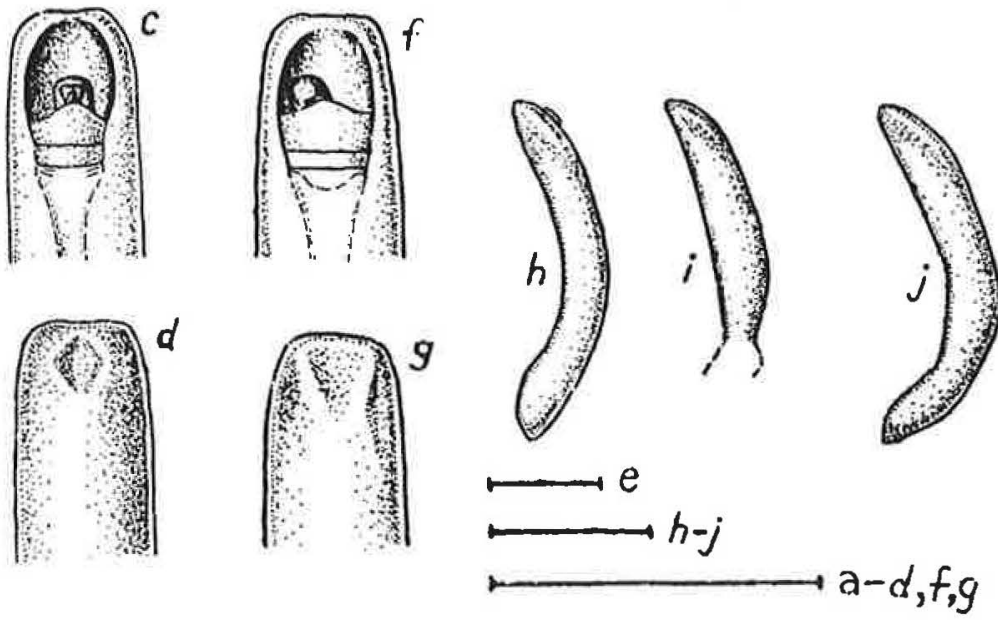
$-1 \mathrm{~mm}$.

greened, small, rather densely, not equally punctured. Lateral impressions wide and deep basally, narrow and shallow medially, somewhat widened and deepen apically, large and deeply punctured; punctures denser apically and basally, single ones spread inside from lateral impressions along base of pronotum. Lateral callus convex for entire length, slightly widened anteriorly, minute punctured. Epipleura separated with longitudinal impression which is dense transversal rugate. Epimera convex. Scutellum equilateral triangular, rounded laterally. Elytra (Fig. 1e) basally not wider than pronotum. Humeral callus slightly convex, elytron slightly impressed behind callus. Elytron with large punctures arranged in: 1 shortened uxtascutellare row, 1 row close to former, which posteriorly approach suture and slightly grooved, and 3 pairs of closed, partly irregular rows, but these rows indistinct by reason of large, dense, irregular punctures in interspaces of row pairs. Each elytron with 4 smooth, very shiny, somewhat convex longitudinal bands, devoid of punctures, and smooth, somewhat convex, very minute punctured callus along epipleura. Distance between punctures in rows and their diameter equal. Elytra not shagreened, interspaces between punctures tiny punctuated and rugulose. Epipleura oblique, visible for entire length in side view, short pubescent in apical part. Sutural angle right, narrowly rounded. Wings develop, 


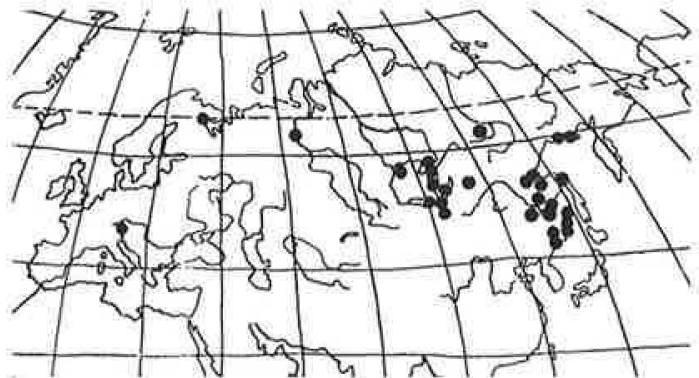

Fig. 2. Distribution of Chrysolina relucens (Rosenhauer).

reach apex of abdomen, but slightly reduced. Legs: tibiae near apex dense fulvous pubescent. Tarsal joint 1 wide, elongated triangular; in fore tarsi this joint slightly shorter and wider than in middle and hind ones, with sparse setae above, smooth and narrow at base, entirely pubescent in the remaining part below. Joint 2 narrowest, triangular, with sparse setae above, entirely pubescent below. Joint 3 entirely pubescent below, slightly wider in males than in females. Claw joint thin and long, with 4 setae below. Metathorax and abdomen light pubescent. Last abdominal sternum slightly impressed basally in males, convex and moderately or slightly turned back, or entirely not turned back at apex in females. Pygidium equably convex, in basal half with longitudinal groove, dense light pubescent. Male genitalia, or aedeagus (Fig. 1a-d, f-j) long, thin, more or less curved, of almost equal width in entire length, narrowed and rounded at apex in side view, oval in transverse section, somewhat grooved above, slightly narrowed at sides of apical opening, widely obtused and weak impressed at apex, with longitudinal impression near apex below. Length 5.9-6.9 mm (males), 6.0-7.6 mm (females); width 3.9-4.9 mm (males), 4.0-6.2 $\mathrm{mm}$ (females).

Distribution (Fig. 2). C. relucens is known to occur in the Alps, the White Sea shore, north of West Siberia, East Siberia and the Far East. According to Breit (1920), this is a relict palaearctic species, formerly widely distributed. Probably it died out over most of Europe and West Siberia during the glacial epoch. Afterwards C. relucens apparently spread from the southern part of East Siberia and the Far East to West Siberia and northern Europe, like Phaedon concinnus Stephens, 1834, and Gonioctena sundmani Jacobson, 1901 (Medvedev \& Dubeshko 1992).
Biology. C. relucens is an Alpine species in central Europe. Rosenhauer (1847) remarked that it was captured at an altitude of $900 \mathrm{~m}$, under stones. All specimens from northern Europe were collected on the White Sea shore under decaying algae overgrown with grasses. I kept the beetles in the laboratory in cages with different plants taken from their locations. The beetles gnawed only the leaves of Sonchus humilis $[=S$. arvensis var. maritimus] (Asteraceae). According to data on the labels, this species inhabits lowlands, hills and mountains up to an altitude of $2000 \mathrm{~m}$, existing mainly in river valleys, lake and sea shores in Siberia and the Far East. Information on host plants is missing from the labels. All specimens were captured from the end of April to the beginning of October. One male found on 1.VIII.1968 in Primorye Territory is feebly chitinized. The date of its capture obviously corresponds with the period of emergence of the young generation of beetles. Immature stages are still not known.

Systematic position. In its colouration, shagreening and puncturing of the pronotum and elytrae, the structure of the maxillary palps and the female last abdominal sternum, C. relucens is similar to the species of the subgenus Anopachys (sensu Bechyné 1952). However, this author (Bechyné 1948, 1952) identified C. relucens as a species of the subgenus Chrysomorpha which differs from Anopachys mainly by slightly convex, not turned back last abdominal sternum in female. The most available females of $C$. relucens have a convex, moderately or slightly turned back last abdominal sternum like females of $C$. aurichalcea - type species of Anopachys (specimens from my collection were examined). Only a few females of $C$. relucens have entirely not turned back last abdominal sternum. Therefore, $C$. (Chrysomorpha) relucens is transferred to $C$. (Anopachys) relucens.

\section{Key to species of subgenus Anopachys Motschulsky, 1860}

A key to species of subgenus Anopachys based on Breit 1920, Lopatin 1990, Medvedev 1992, Warchałowski 1993, and specimens from my collection is set out as follows: 
1. Wings develop, at least cover abdomen. Humeral calli convex, elytrae somewhat impressed behind them .. 2

-- Wings reduced, not longer than metathorax, or absent. Humeral calli absent, elytrae equally convex at sides... 5

2. Aedeagus slightly widened and obtused at apex. Black with weak bronzed tint above. Pronotal disc shining, scarcely microscopic punctured. Korea, E. China ..... C. (Anopachys) gensanensis (Weise, 1900).

- Aedeagus narrowed or anchor-shaped. Metallic-shiny above

\section{3}

3. Pronotal anterior angles weak produced. Pronotal disc rather densely and largely punctured. Aedeagus weak, gradually narrowed in apical part, cut off almost straight at apex. S. Slovakia, Austria

C. (Anopachys) eurina (Frivaldszky, 1883).

- Pronotal anterior angles strongly produced. Aedeagus with parallel sides through almost whole length .... 4

4. Aedeagus more or less narrowed laterally near apical opening, anchor-shaped widened at apex. Pronotal disc weakly convex, covered with uneven dense small or large punctures. Lateral callus of elytrae flat or weakly convex, clearly densely, fine or large punctured. Palaearctic

... C. (Anopachys) aurichalcea (Mannerheim, 1825).

- Aedeagus slightly narrowed laterally near apical opening, wide rounded and weak impressed at apex. Pronotal disc convex. Lateral callus of elytrae convex and scarcely, microscopically punctured. The Alps, N. Europe, north of W. Siberia, E. Siberia, the Far East

C. (Anopachys) relucens (Rosenhauer, 1847).

5. Aedeagus hardly widened laterally near apical opening, rounded and narrowly obtused at apex. The Far East C. (Anopachys) lineella (Weise, 1887).

- Aedeagus weakly, almost rectilinearly narrowed laterally near apical opening, obtused at apex. The Far East C. (Anopachys) lineigera (Jacobson, 1901).

Acknowledgements. I am very grateful to Dr. L. N. Medvedev, Dr. O. N. Kabakov and Mr. A. A. Klimenko for the submitted material, to Prof. G. S. Medvedev for the possibility to work with the Chrysomelidae collection of the Zoological Institute of the Russian Academy of Sciences, to Dr. J. Muona and Dr. H. Silfverberg for a number of valuable remarks on the manuscript, and to my wife $\mathrm{M}$. Ja. Orlova-Bienkowskaja for her help in the preparation of the manuscript.

\section{References}

Bechyné, J. 1948: Notulae ad cognitionem generis Chrysolina Motsch. 3. - Entomologické Listy 11: 10-15.

- 1952: Achter Beitrag zur Kenntnis der Gattung Chrysolina Motsch. (Col. Phytoph. Chrysomelidae). - Entom. Arbeiten aus dem Museum Gg. Frey 3: 351-385.

Breit, J. 1920: Chrysomela - Studien 2. -- Koleopterologische Rundschau 8(7-12): 81-88.

Kippenberg, H. \& Döberl, M. 1994: Familie: Chrysomelidae - In: Die Käfer Mitteleuropas. 3. Supplementband. Krefeld: 17-144.

Lopatin, I. К. (Лопатин, И. К.) 1990: New and littleknown Chrysomelid beetle species (Coleoptera, Chrysomelidae) of the USSR fauna. - Acad. Nauk Ukrainskoi SSR Inst. Zool.: 48-54. (In Russian.)

Medvedev, L. N. (Медведев, Л. Н.) 1992: [Chrysomelid beetles.] - In: Ler, P. A. (ed.), [Key to insects of the Far East of USSR.] 3(2): 533-602. (In Russian.)

Medvedev, L. N. \& Dubeshko, L. N. (Медведев, Л. Н. и Дубешко, Л. Н.) 1992: [Key to Chrysomelid beetles of Siberia.] — Irkutsk University Press, Irkutsk. 224 pp. (In Russian.)

Rosenhauer, W. G. 1847: Beiträge zur Insecten - Fauna Europas 1. Theodor Blaesing, Erlangen. 160 pp.

Warchałowski, A. 1993: Chrysomelidae. Stonkowate (Insecta: Coleoptera) 3. - Fauna Polski 15: 1-279.

Weise, J. 1916: Chrysomelidae 12. Chrysomelinae. - In: Junk, W. \& Schenkling, S. (eds.), Coleopterorum Catalogus. 1-255. 